\title{
Hebrew Palaeotypes in the Collection of the St. Petersburg IOM, RAS
}

Abstract: The present paper is actually a review of Hebrew palaeotypes (i.e. books printed in a Hebrew font between January 1, 1501 and January 1, 1551) kept at the IOM, RAS. It gives a brief description of the ways in which the collection was formed along with the numbers and genres of the books, while also identifying particularly noteworthy items.

Key words: Palaeotypes, publishing, Hebrew literature, incunabula, the Friedland collection, 16th-century printing houses

The IOM, RAS has a significant fund of old Hebrew books. Its core came from a private collection belonging to a well-known benefactor and collector, Moshe Arieh Leyb ${ }^{1}$ (Lev Faivelevich) Friedland who donated his library to the Asiatic Museum of the St. Petersburg Academy of Sciences in 1892. As time went on, the collection kept growing, with the addition of books from private libraries of famous scholars, copies of all books printed in the Russian Empire and those confiscated from synagogues and Jewish schools after the revolution of 1917. A number of them were seized in other countries at the end of WWII as trophies, etc. Consequently, the collection traditio-

(C) Ekaterina Olegovna Shukhman, Institute of Oriental Manuscripts, Russian Academy of Sciences

${ }^{1}$ In this paper, all names and titles follow the so-called simplified translation with elongated vowels, glottal or duplicated consonants remaining unmarked. The character ' $ה$ ' ir rendered as ' $h$ '. The articles are not separated from the nouns, but the nouns themselves start with capital characters. Wherever needed, the titles have been translated (in brackets). Hebrew titles are indicated in footnotes. All geographical names have been standardized, except Istanbul, which is always cited as Constantinople. 
nally referred to as the Friedland Library (Bibliotheca Friedlandiana) has by now grown to an impressive size. In the beginning, the books were actually kept at the Asiatic Museum (after 1917, part of the Oriental Institute) situated in the building of the Library of the Academy of Sciences; later, in the 1950s when the Institute was moved to Moscow, the collections of manuscripts and books were left behind. Approximately at the same time, its Leningrad department was moved to the Novomikhailovsky Palace. The Hebrew collection, however, remained in its place, at the AS Library, until the 1990s. Presently, the books are stored at the Institute of Oriental Manuscripts of the RAS, which is in effect a reincarnated Asiatic Museum. Due to certain historical reasons, the greater part of the collection still remains undescribed and therefore out of researchers' reach.

The most valuable part of the collection are incunabulae and palaeotypes. The former, constituting a separate fund, have been catalogued and described by S.M. Yakerson. ${ }^{2}$ Chronologically, these were followed by palaeotypes. This is a conventional designation for all books printed in a Hebrew font between January 1, 1501 through January 1, 1551, the period universally considered the "golden age" of Jewish book printing. It was during those years that a large number of printing houses emerged, the genre range expanded considerably and print-runs kept growing. The main difference between incunabulae and palaeotypes was the inclusion of title pages, which are even nowadays regarded as the basic source of bibliographic information. However, the palaeotypes still contained colophons that are usual in manuscripts and incunabulae and those retain significant historical value. During the same period, pagination was introduced. All this allows us to say that it was during the five decades in question that the printed book finally acquired its modern appearance.

At present, the collection of old Jewish books kept in the IOM, RAS is being reviewed so that all the palaeotypes can be separated and properly described. Their exact number will become clear only after the work is finished, as quite often several treatises by a certain author or on a similar topic were united in a single binding regardless of the date when they were printed. Consequently, the search for all publications from the given period involves an attentive examination of every single volume within a library numbering tens of thousands of items. However, it is already evident that the IOM, RAS has a fairly comprehensive collection and the books are in

${ }^{2}$ YAKERSON 1985. 
excellent condition. Naturally, this paper is not the right place to provide a complete description of the part already dealt with, so I will have to simply offer a brief outline of the history of the collection and its composition, while drawing the reader's attention to the most remarkable pieces.

\section{The Collection in Its Development}

To date, 264 palaeotypes have been discovered in the collection kept at the IOM, RAS, comprising 237 separate publications (including convolutes but without duplicates). Of those, only 102 bear the mark of Friedland's collection; the remaining 162 books have come from other sources. Most books bear the signatures of previous owners; occasionally, new owners tried to eliminate the inscriptions made by their predecessors, deleting them or even cutting them out. In most cases, these signatures can be found on the title pages, on the fly-leaves, or near the end, after the colophon. Though valuable historical sources in themselves, the signatures cannot indicate the specific library to which the books once belonged, as none of them are repeated; all the signatures are unique. Private owners desiring to avoid losses mainly used book-plates and stamps. This paper seems a suitable place to list those later sources of the IOM, RAS palaeotype collection.

I have already stated that the collection started with the library of L.F. Friedland, donated by him to the Asiatic Museum. In his own words, the library included " 300 handwritten volumes, some of those written on parchment, 32 incunabulae printed in the 15th century, 10,000 volumes, most of them printed in the 16th and 17th centuries, and a number of books in various languages dealing with Jewish literature and bibliography." 3 According to bibliographer Samuel Wiener, who worked with Friedland's library and catalogued it, the collection was based on the library of Issakhar Bampi of Minsk, which Friedland had bought in its entirety. Besides minor collections purchased elsewhere in the Russian Empire and other countries, the collector acquired the following rarities: about 1,000 volumes that were absent from the Bampi library but present in the one owned by Lipman-Rabinovitch of Minsk; the huge library of Rabbi Shlomo (Solomon) Zuckerman ${ }^{4}$ of Mogilev, and a collection assembled by Rabbi Mendel Landsberg of Kremnitz. These three collections also contained books from the famous library of Rabbi Joseph

\footnotetext{
${ }^{3}$ YAKERSON 2008, 56, pl. 29.

ש' צוקערמאן. 4
} 
Mazel of Vyazin; a few thousand rare and expensive books from the library of Rabbi Rabinowitsh of Munich. ${ }^{5}$ All the books from the Friedland collection bear his stamp, but other stamps, signatures and book-plates remaining from previous owners make it possible to trace the routes by which they reached Friedland. For instance, Perush al haTora (Explanation of the Pentateuch) ${ }^{6}$ written by Menahem Ricanati and printed in Venice by Daniel Bomberg in 1523 (des. Fr K 2629) bears, along with Friedland's stamp and the inventory number of the Asiatic Museum, a stamp of Tzukerman's library with a corresponding number.

Three palaeotypes from the Friedland collection bear stamps of Ephraim Deinard's bookstore in Odessa. Deinard (1846-1930) was an outstanding bibliophile; as a book dealer he maintained contacts with virtually all major collectors and libraries across Europe and the USA, so it is no wonder that Friedland used to be his regular customer.

From all his collections, Friedland selected duplicates, which he donated to the Beyt Midrash in Tartu (Derpt) in 1890. In all, he sent about 1,500 volumes there: Talmudic treatises and commentaries, commentaries on the Bible, sermons, cabbalistic texts, and manuals. Of those, two were palaeotypes: Abydarham (named after its author) ${ }^{7}$ printed in Constantinople in 1513, and in Venice in 1546. Both editions can be found in the IOM, RAS collection (des. Fr L 163 and Fr L 3 respectively), but strangely the Venetian one does not bear Friedland's stamp and must therefore have been acquired elsewhere. Friedland possibly sent some duplicates to Jerusalem in 1899 , for the library he founded in an old people's home. Among them was a palaeotype Beur haTora (Explanation of the Pentateuch) ${ }^{8}$ by Bahya ben Asher (Venice, 1546), no copy of which has yet been found in the IOM, RAS collection.

We know little about the personal library of Samuel Wiener (1860-1929), the bibliographer who worked with the Friedland library and catalogued it. We can only say that he collected books all his life and accumulated about 10,000 volumes in Hebrew and 3,000 in Yiddish. Besides, he owned a unique collection of around 4,000 Jewish leaflets (IOM, RAS official site, 2011). Among the IOM, RAS palaeotypes there is a book with his personal

\footnotetext{
${ }^{5}$ WIENER 1893, 3.

ריקאנאטי, מנחם בן בנימין. פירוש על התורה. 6 אבודר. 6

אבודרהם, דוד בן יוסף. אבודרהם. פליה.

בחיי בן אשר אבן חלאוה. באור התורה. 8 יוסריהם 8
} 
stamp (without Friedland's), written by Shem Tov ben Joseph ibn Shem Tov, a prominent 15th c. philosopher and preacher (died in 1493): Drashot haTora (Biblical sermons) ${ }^{9}$ (Saloniki, 1525) (des. Fr L 25). It might be of interest to note that this book bears several impressions of Wiener's stamp, but only one of them, placed approximately in the middle of the volume, is properly legible: all the others were at some point in time partially masked with black ink - his name in Hebrew characters especially thoroughly. So far, this is the only book from Wiener's personal library that has been found in the IOM, RAS collection.

In 1909, the Asiatic Museum purchased Professor D.A. Chwolson's library with its Hebraic part including a number of palaeotypes as well. So far five items bearing Khvolson's book-plates have been discovered. Among them are two editions of the religious digest $\mathrm{Kol} \mathrm{Bo}$ (Everything in it) ${ }^{10}$ (Rimini, 1520 and Venice, 1547) (des. Fr L 164 and Fr L 19 respectively), and a first edition of Jehuda haLevi's philosophical treatise Kuzari ${ }^{11}$ (Fano, 1506) (des. Fr K 2574).

During the 1930s, the collection of Jewish books and manuscripts absorbed the stocks of the National Karaite Library in Evpatoria (Karay Bitikligi). The only palaeotype bearing its stamp as yet discovered is Seder haTefillot leMinhag kahal haKaraim. Minchat Jehuda (Karaite prayer-book. Jehuda's prayer. In five volumes. Venice, 1528-1529) ${ }^{12}$ (des. Fr K 2814). It carries an inscription specially mentioning that the book was donated by a prominent 20th c. Karaite scholar, I.Y. Neyman-Kruglevitch, a research fellow at the State Palace-Museum of the Turkic culture in Bakhchisaray. The personal archives of that famous scholar are also kept at the IOM, RAS.

Possibly at the same time as manuscripts and books were being confiscated from Crimean Karaite Jewish kenasas and synagogues, the collection acquired two copies of the Karaite legal code Aderet Eliyahu (Eliyahu's cloak) composed by Eliyahu Bashiyachi ${ }^{13}$ (Constantinople, 1530) (des. FR M 74). One of them had been donated to the Karaite Theological Academy by I.B.Z. Kaplanovsky (a fact attested by the book-plate), the other came from the Rayetzky brothers' library (the Lutsk Karaite

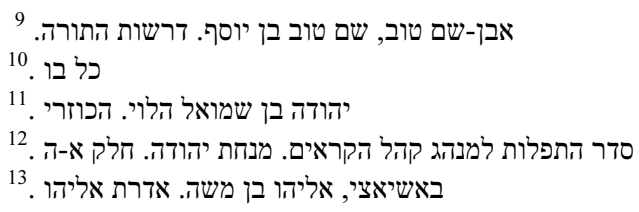


synagogue). In all, the collection has three copies of this edition (the third one had been bought by Friedland from Ephraim Deinard in Odessa).

Among other private, mostly probably, European collectors who marked their books with book-plates and stamps, mention can be made of Frederik Muller of Amsterdam (1 book), Marco Camajoli (3 books, one also bearing Friedland's stamp), Fr. Rabut Cumbs (1 book), B.C. Reichard (2 books, also bearing Friedland's stamp).

One gem of the collection is a book from the personal library of Samuel (Shmuel) de Archivolti, a Jewish writer and grammarian ${ }^{14}(1530-1611)$. It is the second edition of Machberot Emanuel (The Emanuel Notebooks) ${ }^{15}$ (Constantinople, 1535), poems by Emanuel the Roman who also commented upon the Pentateuch. Originally, the collection had been printed in 1491 in Brescia by Gershon Soncino, and after that in Constantinople, by his son Eliezer. Professor Khvolson described this anthology as excellent and brilliant, written by a 13th c. Heine, sparkling with genuine humor. The great codifier of Jewish law Joseph Karo, though, forbade people not only to read it on the Sabbath, but even to print it, as "the publishers promoted sinning". As a result, a third edition did not appear until 1796 (Berlin), when Enlightenment ideology prevailed thanks to Moses Mendelsohn's friends and disciples. ${ }^{16}$ Thus printed copies of that anthology are extremely rare; the IOM, RAS has two (des. Fr K 2253). As has already been mentioned, one of them once belonged to Samuel Archivolti whose name is stamped in gold on its leather binding. The other copy bears the library stamp of "Ducalis Gothana" and is in excellent condition.

A real treasure in the IOM, RAS collection is the 4th volume of the Jewish Bible ${ }^{17}$ Arbaa weEsrim Gadol (Twenty-four [books]) ${ }^{18}$ (Venice, 1546-1548) (des. Fr M 129). This edition of four folio volumes is represented in the collection in its entirety. However, the first three volumes were donated by Friedland, while the fourth came from the library of Sigismund II Augustus (1520-1572), the King of Poland and Grand Duke of Lithuania, an inveterate bibliophile who assembled a large library, mostly on the humani-

\footnotetext{
${ }^{14}$ Samuel de Archivolti.

15. עמנואל בן שלמה הרומי. מחברות עמנואל

${ }^{16}$ KHVOLSON 1896, 28.

${ }^{17}$ Scholars use the term Jewish (or Masoret) Bible to denote the Biblical canon established and codified by Judaic tradition (Biblia Hebraica).

ארבע ועשרים גדול. 18
} 
ties, which later became the basis of Vilnius University library. Presently, the 82 volumes from the collection of Sigismund II are kept at the Library of the Academy of Sciences; in 1994, they were catalogued. ${ }^{19}$ This volume, like all the others from that collection, has a distinctive binding made in Vilnius during the King's lifetime. The front cover carries Sigismund Augustus's double coat of arms: the Polish Eagle and the Lithuanian "Chaser". The back bears the stamped inscription: "Sigismundi Augusti Regius Polonia monumentum". The LAS received the book in 1927 from the St. Petersburg Roman Catholic Theological Academy, as is attested by a sticker on the spine: "Bibliotheca Romano-Catholica ecclesiasticae Academiae Petropolitana".

Concluding the discourse, I note that 44 palaeotypes at the IOM, RAS have no handwritten notes or stamps whatsoever (except the modern stamps of the IOM, RAS and the inventory number). They are not even signed by censors. Naturally, a lot of the 16th c. volumes have been damaged by water, fire or bookworms, but there are some that look like they have just come from the printer.

\section{The Composition of the Collection}

The palaeotypes in the IOM, RAS make it possible to get an idea of the genre diversity of Jewish books printed in the early 16th c. A significant portion of them are religious in character or else on such naturally related topics as didactics, law and philosophy. Due to Europeans' increased interest in Hebrew studies, grammar and reference books were in demand. Fiction was also popular.

The collection contains 15 editions of separate Biblical books, 3 complete Venetian editions of the Jewish Bible printed in 1517, 1524, and 1546 (des. Fr M 121; Fr M 123, and Fr M 129 respectively). Especially notable are two rare volumes of translations of the Pentateuch, each in a pair of languages. The Arabic and Persian edition (Constantinople, ed. Eliezer ben Gershom, ${ }^{20}$ Soncino, 1546) (des. Fr L 37) is in a poor condition, with both its beginning and end missing. Still extant are Gen. 17:-5-49:26; Ex. 6:5 to the end; Lev. and Num. completely, Deut. up to 11:6. The Greek and Spanish edition

\footnotetext{
${ }^{19}$ SAVElyeva 1994.

אליעזר בן גרשם שונצינו. 20
} 
(Constantinople, ed. Eliezer ben Gershom, Soncino, 1547) (des. Fr L 49) is in an equally poor state with Genesis missing altogether. The extant sections of the other books are: Ex. from 10:22, Lev. complete, Num. up to 7:75 and 11:1-11:14, Deut. from the end of 10:22 to 11:12. In all, of the 390 ff. just 116 have survived and of those ff. 24, 37-39, 84, 107 and 108 only partially.

The collection also includes a few early editions of Talmud and its separate treatises, among them 8 of the 23 treatises of the Babylonian Talmud printed by Gershom Sonchino in Pesaro in 1508-19 (des. Fr L 56; Fr L 58, Fr L 60; Fr L 61; Fr L 62, Fr L 26, Fr L 59, Fr L 57). A particular pride is the first Venetian edition of the Talmud (1519-1524) (des. Fr M 130). It was in Daniel Bomberg's printing house in Venice that the printed Talmud acquired the form that is still retains today: pagination was introduced, the text was accompanied by the commentary by R. Shlomo Yitzchaqi (RaSHI) (1040-1105) ${ }^{21}$ and Tosaphot, ${ }^{22}$ along with other commentaries positioned after the relevant treatise. Subsequently, it became traditional to print the Talmud preserving the pagination of the Venetian edition, even when the text was split into pages in a different way (cf. the Viennese edition). Thus every printed copy of the Talmud has 2947 numbered folios or 5894 pages which makes it possible to precisely cite any given passage. All references contain the title of the treatise, the folio number, and the indication of its side.

A significant part of the collection consists of studies by Jewish experts in religion. There are, for instance, 8 editions of works by Maimonides (RaMBaM) (1135/38-1204), ${ }^{23}$ the earliest being a large copy of Mishne Tora in two volumes (Constantinople, 1509) (des. Fr L 25) (des. Fr L 53); 4 editions of studies by Nachmanides (RaMBaN) $(1194 \text { - after } 1270)^{24}$ (the earliest printed in Constantinople in 1510) (des. Fr K 463); 4 editions of works written by Yitzchak ben Yehuda Abrabanel, a philosopher and commentator $(1460 \text { - after } 1523)^{25}$ (the earliest printed in Constantinople in 1505) (des. Fr K 2422); 5 editions of commentaries on various Talmudic treatises (Venice, 1523) (des. Fr L 192, (a convolute); Fr L 193 (a convo-

ר' יצחק בן שלמה (רש"י). 21

22 - commentaries on the Talmud compiled by a group of rabbis and Talmudic scholars who lived in France in the 12th and 13th cc.

משה בן מימון (רמב"ם). משנה תורה. 23

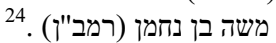

אברבנאל, יצחק בן יהודה . 
lute); Fr L 197 (a convolute) and an edition of Responses (Bologna, 1529) by a major Rabbinical expert Shlomo ibn Aderet (1235-1310). ${ }^{26}$

Of significant interest are two compositions by Abraham Bibago, a 15th c. Spanish Jewish philosopher and preacher (died before 1489): Derekh Emuna (Path of Truth) ${ }^{27}$ (Constantinople, 1521) and Ze Yenachamenu (This will comfort us ${ }^{28}$ (Saloniki, 1522). Both have only been printed once. Derekh Emuna is a philosophical study on faith and religion; the author explicates a lot of passages from the Bible and Talmudic literature, referencing Moslem and Christian theologies. Bibago was notably vitriolic in his defense of Maimonides's credo attacked by his opponents. Ze Yenachamenu is a sermon based on the book of Genesis, telling about Creation and the Sabbath. Bibago was fairly well known among Jewish scholars and philosophers, but his works did not gain universal acceptance. This is a possible reason why his major opus, although frequently quoted by other philosophers, e.g. Abrabanel, was never reprinted (while another book, Etz Chayim (Tree of Life) mentioned in Derekh Emuna was not printed at all). In the IOM, RAS collection the two publications are united in a single binding (des. Fr L 50).

Linguistics is fairly well represented in the IOM, RAS collection. There are five editions of works by Eliyahu Levita ${ }^{29}$ a Hebrew philologist, grammarian and lexicographer (1458-1539). Diqduq Eliyahu (Eliyahu's Grammar) ${ }^{30}$ (Isni, 1542) (des. Fr K 2456) discusses the grammatical functions performed by vowels and consonants; an identical book exists under the title haBachur ${ }^{31}$ (The Chosen One, a nickname of its author) (Isni, 1542) des. Fr K 1363); Masoret haMasoret ${ }^{32}$ (The Masoretic Tradition) (des. Fr K 2791) proved, for the first time ever, that punctuation and cantillation signs had not been in existence since Moses' time and, indeed, were not invented before the Talmud was finished; the same signs are dealt with in his composition Tov taam ${ }^{33}$ (Good Understanding) (des. Fr K 2573) (both books: Venice, 1538). Finally, there is a dictionary, Meturgeman ${ }^{34}$ (Translator), of

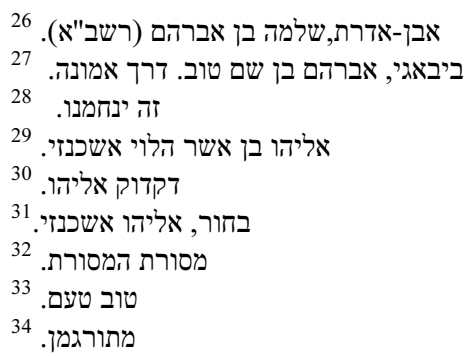


the Aramaic language used in targums (Isni, 1541) (the IOM, RAS has two copies of this, des. Fr L 55). Thanks to the clarity of Levita's language, his books (which were also translated into Latin) promoted the study of Hebrew and its grammar among Jews and Christians alike.

The works of David Qimchi (ca. 1160-1235), ${ }^{35}$ another famous Jewish grammarian and Biblical commentator, are represented in the collection by three editions: Sefer ha Mikhlol (Book of Perfection) (Constantinople, 1533) (des. Fr L 38) is a systemized Hebrew grammar; Sefer haShorashim (Book of Stems) ${ }^{36}$ (des. Fr. L. 27), a lexicon of Hebrew, is considered the second part of that grammar treatise (Constantinople, 1513, and a later edition, Venice, 1529). The collection includes the third edition of another grammar that was written by David's brother, Moshe Qimchi (died in 1190), Diqduq (Grammar) $^{37}$ (Ortona, 1519 (des. Fr K 197). Its full title was Mahalakh sheviley haDaat. Darkhey Leshon haQodesh ${ }^{38}$ (Going along the path of knowledge. The ways of the holy language). This work was first printed in Soncino in 1488 . The IOM, RAS has a copy of that incunabula. ${ }^{39}$ Translated into Latin by Sebastian Muenster, that book was a highly popular Hebrew grammar among 16th c. Christian linguists.

In the collection, there are three editions of a major Talmudic dictionary, heArukh (The Systemized [dictionary]), ${ }^{40}$ compiled by Natan ben Yehiel of Rome (1035-1110) and first printed in 1470 in Rome. Our collection contains the second abridged edition (Constantinople, 1511) (des. Fr K 2507), the third (Pesaro, 1517) (des. Fr L 8, two copies) and fourth (Venice, 15311532) (des. Fr L 176).

Another interesting item is the only edition of a book by Shlomo ben Abraham of Urbino (died ca. 1513) with the title Ohel Moed ${ }^{41}$ (Ark of Covenant) (Venice, 1548) (des. Fr K 1664). This is an encyclopedia of sorts, with the words arranged in the alphabetical order of their stems. It was reprinted in Vienna in 1881 , but $75 \%$ of that publication consisted of commentaries on the basic text.

\footnotetext{
קמחי, דוד בן יוסף.

ספר השרשים.

קמחי, משה בן יוסף. דקדוק.

מהלך שבילי הדעת. דרכי לשון הקודש. מדוק.

${ }^{39}$ YAKERSON 1985, No. 50

נתן בן יחיאל מרומא. הערוך. 40

שלמה בן אברהם מאורבינו. אהל מועד. 41
} 
An important contribution to the development of Hebrew studies was the first edition of the concordance of the Jewish Bible by Yitzchaq Natan ben Qalonimus, Meir Nativ (Illuminating the Path) ${ }^{42}$ (Venice, 1524) (des. Fr M 122). In this work, the author followed the methods developed by the scholars who compiled Latin concordances: the Biblical books to which he referred were listed in the order in which they were arranged in the Vulgate. Additionally, he divided them into chapters ("capitula") and numbered the verses. His study opened with a list of all sections of all books of the Jewish Bible with an indication of their initial words. The headwords were arranged according to their stems, a principle later observed in virtually all Hebrew concordances.

Fiction is represented in the collection, among everything else, by a highly interesting collection of poetry Shirim uZemirot (Verses and Poems) ${ }^{43}$ (Constantinople, 1545) (des. Fr K 1656) containing 298 vocalized poems, songs and religious hymns. Most of them had been written by medieval poets: Shlomo ibn Gabirol (1021-1055/70) ${ }^{44}$ Yehuda haLevi (1075-1141), ${ }^{45}$ Abraham ibn Ezra (1055-1139), ${ }^{46}$ etc. About 60 poems were written by R. Mazal Tov ben Shlomo, ${ }^{47}$ who was the probable creator of the compilation. The collection was printed as a small narrow $(7 \times 16 \mathrm{~cm})$ book, which was unusual for that time. This particular copy represents additional interest, as it bears an autograph of Samuel Wiener who wrote on the fly-leaf that the book was bought from R. Finn of Vilnius in 1889.

The palaeotype collection includes what might be termed "ground-breaking" publications. For instance, the first ever book with partial pagination, a two-volume Mishne Tora by $\mathrm{RaMBaM}^{48}$ (the printing house of the brothers David and Shmuel ibn Nachmias, Constantinople, 1509) (des. Fr L 53), and the first book furnished with a title-leaf: Sefer haRoqeach (Book of the Apothecary $^{49}$ by Eliexer ben Yehuda of Worms (1165-1230) (Fano, printing house of Gershom Soncino, 1505) (des. Fr L 166). Sadly, the actual title leaf is missing from this copy. Besides, the collection has a copy of

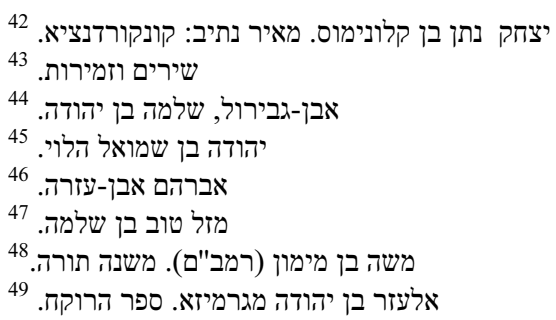


Mashal haQadmoni (Ancient Parable) ${ }^{50}$ by Yitzchaq ibn Sahul, a Spanish Jewish author (died ca. 1282). This work contains fables about animals with satirical commentaries reflecting contemporary events. It was first printed around 1491 at Gershom Soncino's printing house in Brescia, becoming the first illustrated book in Hebrew. The IOM, RAS library possesses a copy of its equally well illustrated third edition (Venice, 1547) (des. Fr K 2504).

In conclusion, I should once again emphasize the exceptional value of the palaeotypes kept at the IOM, RAS. They include publications from most printing houses producing Hebrew books in the early 16th c. Furthermore, the collection contains books in virtually all genres that existed at that time. Most items have title leaves and colophons that are essential sources of bibliographic information. Many contain marginalia and owners' signatures that open up a vast field for further research. A considerable number of the books have extremely valuable artistic bindings. The work of separating and cataloguing these books continues, with the publication of a complete scholarly catalogue of the palaeotypes kept at the IOM, RAS being planned.

\section{References}

Asiatskii muzei Rossiskoi Akademii Nauk 1818-1918. Kratkaia pamiatka. Pb.: Rossiiskaia gosudarstvennaia academicheskaia tipografiia, 1920: Asiatskii muzei Rossiskoi Akademii Nauk 1818-1918. Kratkaia pamiatka. Pb.: Rossiiskaia gosudarstvennaia academicheskaia tipografiia [Asiatic Museum of the Russian Academy of Sciences. A brief note]. Petersburg: Russian State Academic Printing House.

BENJACOV, Isaak 1880: Ozar ha-sepharim. Thesaurus librorum hebraicorum [Collection of books. Dictionary of Hebrew books]. Wilna: ha-Almana veAhim Romm.

FriedBerG, Bernhar 1951: Bet eked sepharim. Bibliographical lexicon [Library. Bibliographical lexicon]. Tel-Aviv: M.A. Bar-Juda.

GrAETZ, Heinrich 1896: Divrei yamim Israel [History of Israel]. Warsaw: Alapin-Schuldberg and Co.

Habermann, Abraham 1978: Ha-Madpiss Daniel Bomberg [Printer Daniel Bomberg]. Zfat: Museum of Printing art.

Khvolson D.A. 1896: Evrejskije staropetchatnyje knigi [Old Jewish printed books]. St. Petersburg: Russian Academy of Sciences press.

NEUBAUER, Adolf 1886: Catalogue of the Hebrew manuscripts in the Bodleian Library and in the College Libraries of Oxford. Oxford: Clarendon press.

POPPER, William 1899: The Censorship of Hebrew books. NY: Knickerbocker Press.

אבן-סהולה, יצחק בן שלמה. משל הקדמוני. 50 
Savel'Eva E.A. 1994: Knigi iz biblioteki polskogo korolia Sigizmunda II Avgusta: catalog [Books from the library of the Polish King Sigismund II Augustus: a catalogue]. Comp. by E.A. Savel'eva. St. Petersburg: Library AS USSR press.

SIRAT, Colette 2003: Istoriia srednevekovoi evreiskoi filosofii [History of medieval Jewish philosophy]. Moscow: Gesharim.

The Bibliography of the Hebrew book (1470-1960) 2002: The Bibliography of the Hebrew book (1470-1960). Jerusalem: EPI and Institute for Hebrew Bibliography.

VINOGRAD, Yeshayahu 2002: Thesaurus of the Hebrew book. Jerusalem: Institute for computerized bibliography.

WIENER S.E. 1893: Bibliotheca Friedlandiana: Catalogus librorum impressorum hebraeorum in Museo Asiatico imperialis Academiae Scientiarum Petropolitane asservatorum [Bibliotheca Friedlandiana: Catalogue of Hebrew books in the Asiatic Museum of St. Petersburg Academy of Sciences]. St. Petersburg: Russian Academy of Sciences press.

YAKERSON S.M. 1985: Katalog inculabulov na drevneevreiskom iazyke biblioteki Leningradskogo otdeleniia Instituta vostorovedeniia [Catalogue of Hebrew incunabulae in the library of the Oriental Institute of the USSR Academy of Sciences the Leningrad department]. Leningrad: Library Academy of Sciences of USSR press.

YAKERSON S.M. 2008: Evreiskie sokrovishcha Peterburga [Jewish treasures in St. Petersburg]. St. Petersburg: Arka.

ZuNZ, Leopold 1895: Gesammelte Schriften [Collected works]. Berlin: Gerschel. 